\title{
LT COL F.F. PIENAAR'S BOER WAR DIARY
}

(PART II)

Brig J.H. Picard, SM*

\section{FREE STATE TO MACHADODORP}

Pienaar asked for and was granted a transfer to the OFS where he was asked to help with the establishment of communications between the Menschvreterberg, site of the Boer Headquarters, and Winburg. It was decided to use wire fences and a vibrator instead of a telephone, as it would take too long to lay a cable. This was a relatively simple process as, by law, every Free State farm had to be fenced along its borders. Therefore, a network of readymade lines already existed. The only procedure necessary to insulate the wire was to walk along the fence, cut the cross-bindings connecting the upper wire to the lower ones, and lay a cable under the gates. Soon messages were gaily buzzing to and fro along the fence wires and, despite interruptions due to cattle knocking over poles; it allowed the Government in Kroonstad to keep in constant touch with the front line.

The enemy continued to gain ground, however, and soon Brandfort had to be given up and not long after that Thabanchu as well. Although President M.T. Steyn' personally visited the positions the strain of attempting to stem the British advance could no longer be sustained. Within a few days orders came to retire to Lindley.

While the British relied on the telegraph system for their communications, this was of little use to the Boers who were always on the move. In any case, the British held all the telegraph stations, however, their lines were constantly being tapped by the Boers and this often happened at crucial moments when a co-ordinated attack was being planned.
Lindley and Heilbron were not directly connected by telegraph and a message from the one to the other had to travel via Johannesburg and Kroonstad, involving a delay of several hours. It was Pienaar's task to make good this missing link but haste was required, for the British were already marching on Kroonstad. The Free State Government was preparing to retire ostensibly to Lindley, but in reality to Heilbron, and the fences of farms along the way still had to be repaired. A few miles out of town Pienaar came upon General C.R. de Wet's ${ }^{2}$ forces, which were just re-

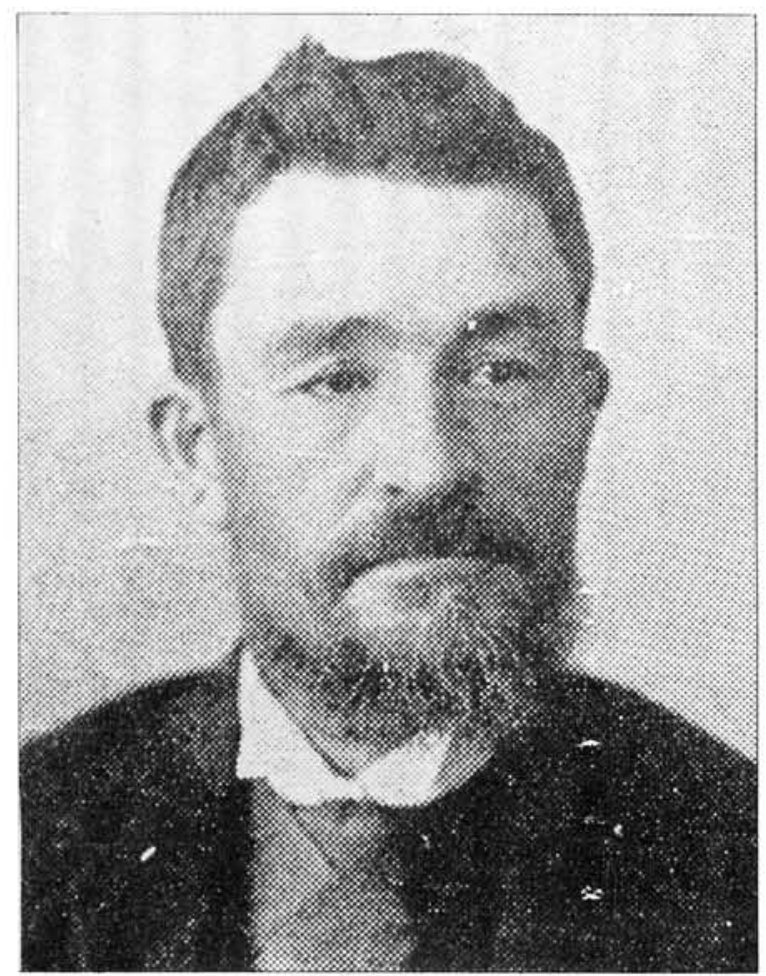

General C.R. de Wet

treating from Ventersburg. En route from Heilbron back to Lindley communication suddenly stopped, On his arrival at the town Pienaar discovered the reason, Lindley had been occupied by the British. 
Pienaar wrote in his diary "We two rode on until almost on top of the hill overlooking Heilbron where we dismounted. Drawing the horses behind a low stone wall, we attached the vibrator to the line." He then called up Heilbron at once, reporting that Lindley was lost. The reaction was: "impossible".

"Please tell the President what I say."

"Here Postmaster-General. The President says impossible. Enemy still in Kroonstad."

"Not much! Here they are, before my eyes. Please believe that there is no mistake." 3

They finally believed and when Pienaar returned to Heilbron, the Postmaster. General took him through to the President who was seated at a table, writing. Although attired in plain black, like most lawyers, there was a dignity in President Steyn's bearing and a strength of character in his manner, that could not fail to make an impression on Pienaar.

"Well, Flippie, where do you come from?" the president asked. Pienaar stammered: "from Winburg. President," alluding to the last time he had seen President Steyn.

"No, no! I mean today."

"Oh, from Lindley. But I could not find out more. Some think their next move will be towards Bethlehem, others think they are coming on here."

"Ah.! Well, I know now that your information was correct, and I am satisfied with your work. I hope that you will continue to be so successful. Now, go out there again, see what they are doing, and report to me."

Pienaar retired, highly gratified.

He then obtained an order from General (Judge) J.B.M. Hertzog, then Chief of Commissariat ${ }^{4}$, to have his pony shod. However, the blacksmith had no nails. So Pienaar obtained these and held a candle for the blacksmith while he shod the horse. Upon noticing that the animal limped, he insisted that the blacksmith re-shoe the horse. The lameness then disappeared.

Towards Lindley fighting was heard. Pienaar signalled on a message received from a despatch rider, adding that there was nothing to stop the enemy from taking Heilbron that night. $\mathrm{He}$ later passed a British column of about 7000 men and when he arrived at Heilbron, found it already deserted.

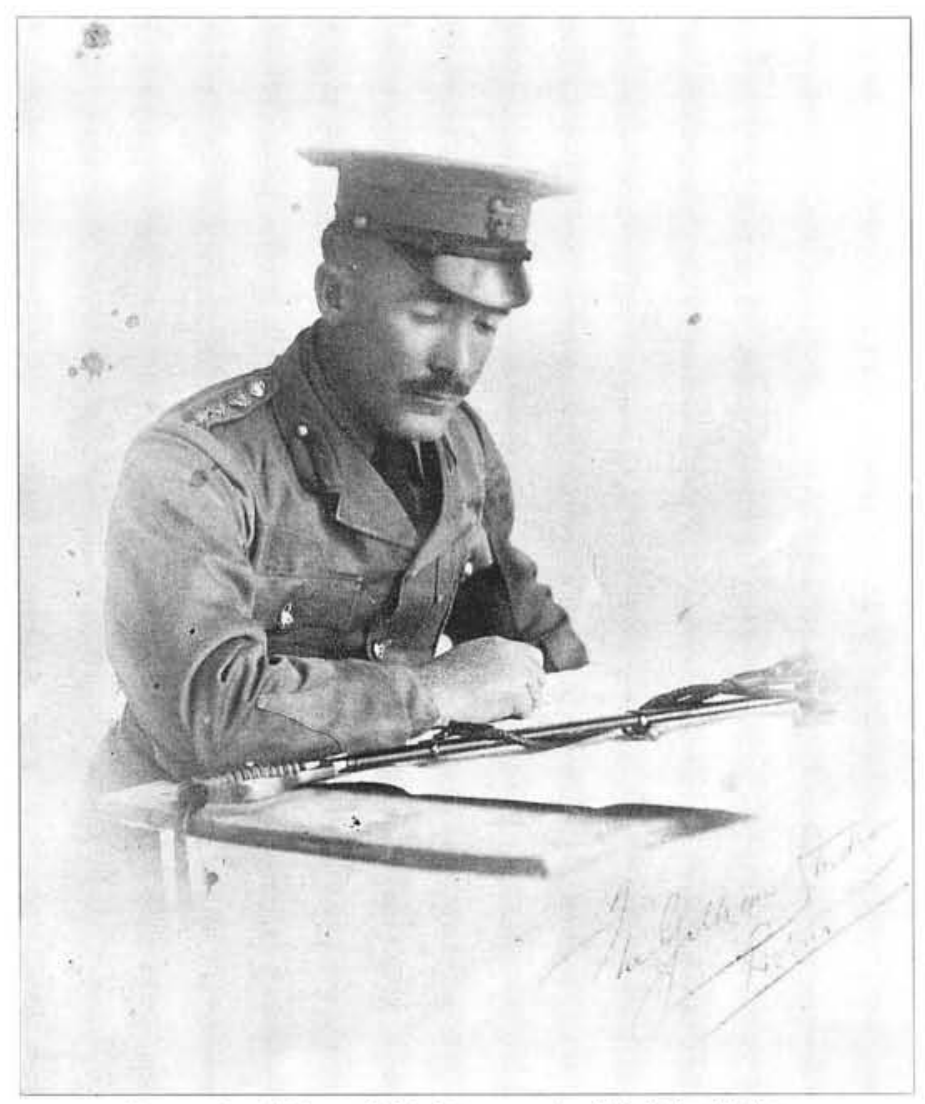

Portrait of Capt F.F. Pienatr in UDF 19/5/10.

SADF Archives (Doc 781003964).

He tapped the lines and discovered that the British were looking for the Boer forces. Pienaar warned President Steyn that the Boer's bonfires betrayed their presence, Steyn then gave the order for all lights to be extinguished. The following morning Pienaar intercepted messages from General Sir Ian Hamilton $^{5}$ to Lord Roberts announcing his arrival at Heilbron and the details of the two engagements fought: including the number of killed and wounded 
and the state of his forces. Pienaar handed the messages to the President who appeared to be very pleased.

Near Heilbron Pienaar intercepted a message detailing the British campaign plans for the next few weeks, including the envisioned future moves of Generals Broadwood 6 and Hamilton. Pienaar moved to Frankfort from whence he communicated the news to General De Wet including the fact that General Hamilton was leaving Heilbron ungarrisoned. This enabled the Boers to capture several hundred sick and wounded that the British had kindly left to their care. Pienaar was later introduced to De Wet whom he found tactless, carelessly dressed and somewhat abrupt. "But," he wrote, "De Wet, if he lacks culture, certainly has an abundance of shrewdness, and is not without some dignity at times. And it is chiefly owing to De Wet and Steyn that the war did not end with the fall of Pretoria."7

Pienaar was sent on, together with Gideon Scheepers, to follow De Wet, who wanted him to tap the British lines near Kroonstad. Pienaar would, however, in no way be subordinate to Scheepers. After helping Scheepers and his men with the heliography. Pienaar told Scheepers how at Spionkop wire-tapping had failed at the very moment it was needed most. "Yes," he remarked thoughtfully, "trifles often make all the difference. We had laid a nice little trap near Kroonstad, put a charge of dynamite on the rails, placed the men in position, and waited for the train to come along. Af- ter a few hours of suspense it appeared and just as it was going over the charge I pressed the button. What do you think happened?"

"The unexpected, I suppose?"

"Precisely. To our disgust the dynamite did not go off and the train puffed tranquilly past. One of my battery wires had become disconnected in the dark. So the whole thing was spoilt."

"At least from your point of view," Pienaar joked. "But think what a narrow escape you had yourselves. The train might have stopped, a searchlight might have shown you up and a volley

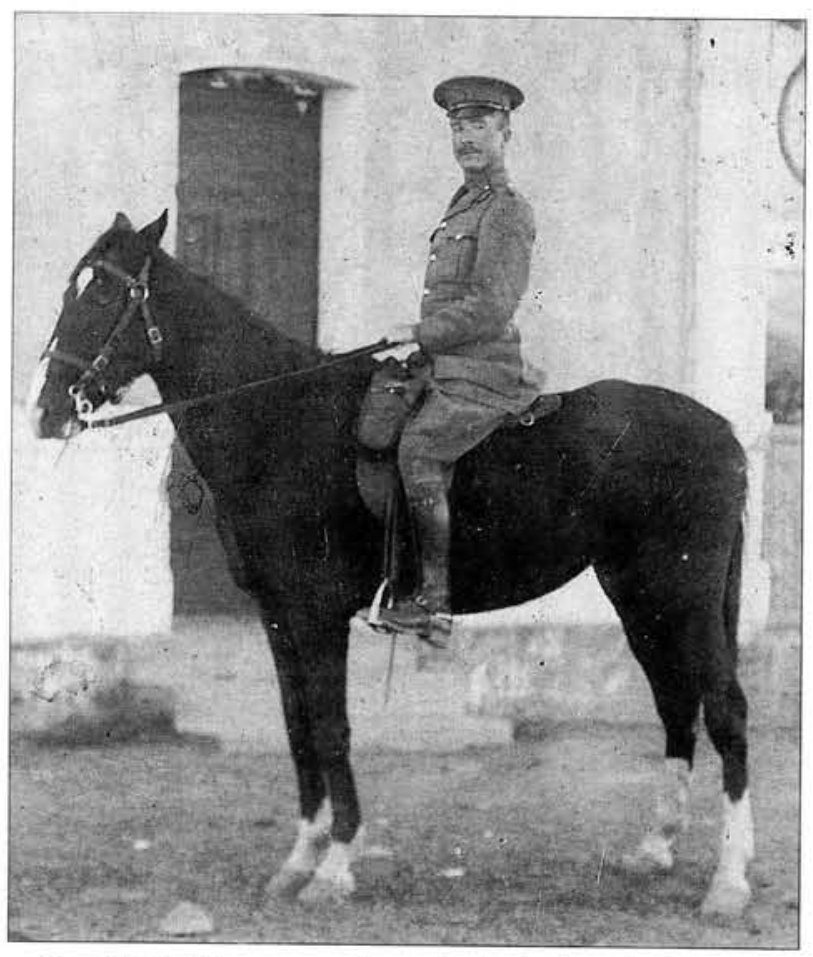

Capt F.F. Pienaar on horseback during the German South West Campaign 1915. Pienaar private collection. from a battery of Maxims might have made mincemeat of you all."

"Oh, no danger of that!" replied Scheepers: "We knew there were no Graphic journalists aboard!"

De Wet did not find Heilbron deserted, Colville had moved fast to reoccupy the town and once again it was full of British troops. They were still unaware of the fact that Boer telegraphers' messages were coming through fast and furious, until Pienaar cut the line.

Scheepers was still away scouting and his men had made no effort to prepare any food. Pienaar began to suffer from hunger. It is hard to realise the extent of the selfishness which generally prevailed in a laager or commando. where it was a case of everyone for himself. There was no regular distribution of rations every day, as in other armies. The commando was divided into messes numbering approximately ten men each. Every mess occasionaly received a live ox and a bag of meal.

\footnotetext{
General R.G. Broadwood (1862 - 1917)

Pienaar, p. 97.

Commandant G. Scheepers (1878 - 1902).

General Sir H.E. Colville (1852 -1927).
} 
The ox was killed and cut into biltong. and the meal baked into stormjagers, a type of dumpling fried in dripping. Scheepers' men were probably not very well off with respect to provisions in any case they offered Flippie nothing and he had to do an awful lot of scouting around to get a meal.

De Wet's magnificent success at Roodewal came as a surprise to Pienaar who had been convinced that the effort would be a fiasco. Danie Theron's corps then came through from the Transvaal to join De Wet. Theron was a slightly built young lawyer, who wore a sad expression due to the premature death of his fiancée. His one hundred and fifty young fellows were keen and disciplined. He took care of his men, fed and horsed them well, led them into hot corners and saw them safely out again.

The affair at Roodewal caused Lord Roberts to send a strong column back in order to keep the Boers off his flanks. When it reached Villiersdorp the Boers fell back from Frankfort towards Bethlehem, where they had set up their new headquarters. A dispatch came from the Transvaal asking for Steyn's presence because things were going badly there. Steyn did not hesitate, and left with De Wet, leaving General J. Prinsloo and over 4000 men behind, with orders to stand their ground.

Pienaar joined the Free Staters who had passed through the cordon of British Forces which lay massed around the mountain chains of the Drakensberg. The Boer forces amounted to 2000 horsemen as well as vehicles. cars and waggons, forming a six mile long procession. When they trekked out of the neck strict orders were given that there was to be no loud talking or matches struck. The latter was especially hard on a crowd of such inveterate smokers, although Pienaar did not smoke at all.

Suddenly someone at the front asked: "Who struck that match?" The delinquent himself replied: "It's this achterryer of mine. Was it you, Jantjie?"

"Yes, Sir," responded the servant, bobbing up and down on his master's spare horse.
"Give him twenty with the sjambok!" "Right!"

Jantjie and his master turned out of the road, and soon the unmistakable thwack! thwack! of the sjambok could be heard, interspersed with subdued explanations in Tswana and Dutch. But judging by Jantjie's smile by the camp fire that night, as he blew long fragrant clouds of expensive tobacco into the gaping nostrils of his envious friends, Pienaar had his doubts about that "thrashing".

After a heavy engagement, the Boers captured a train while crossing a railway line near Heuningspruit. De Wet kept his plans so secret that very few knew for certain where they were bound. Seeing a pretty little cottage in the valley below, Pienaar rode hither to try and buy a loaf of bread, leaving the others to attempt to raise Potchefstroom. The only people at the farmhouse were two young girls. The elder was a charming golden-haired fairy with tender eyes of cornflower blue, and her smile! It was enough to make one say all kinds of silly things. Pienaar naturally delayed his departure for several hours, but when he returned to the camp at last, he had a loaf of bread with him.

Steyn and De Wet had gone up to the heliopost a little while before. What would they say upon finding him absent, Pienaar wondered? As he walked up to the post with dragging feet he suddenly remembered a telegraph line he had seen leading towards Potchefstroom.

"President," he said eagerly, before the president could get in a single word. "There's a telegraph line near here. Shan't I go and try to tap it?"

He looked at Pienaar very seriously for a moment and then replied, a smile breaking through the frowns, "Yes, go on, you should have been there already."

He was saved again!

A band of about thirty Transvalers, mostly from Potchefstroom, who had been attached to De Wet's forces for some time, now decided to go on 
ahead and join Commandant D.P. Liebenberg's ${ }^{10}$ commando near Potchefstroom; Pienaar joined them. In the afternoon they merged with a small commando lying near the railway between Potchefstroom and Frederickstad - barely a hundred men but they had a bomb-maxim and a Krupp. At Frederickstad they were reinforced by a score of burghers who were riding parallel with the railway behind some intervening hills. Presently a scout came in and reported that the enemy had been sighted.

\section{"Forward!" ordered} the Commandant. Keeping the Nordenfeldt in reserve, they opened up on the advance guard of the enemy with the Krupp and small-arms fire. At that time they did not know that they were tackling Lord Methuen"1 and five thousand men. The engagement lasted for about two hours. Then their cavalry came on with a rush and it was only with the greatest difficulty that the small com-

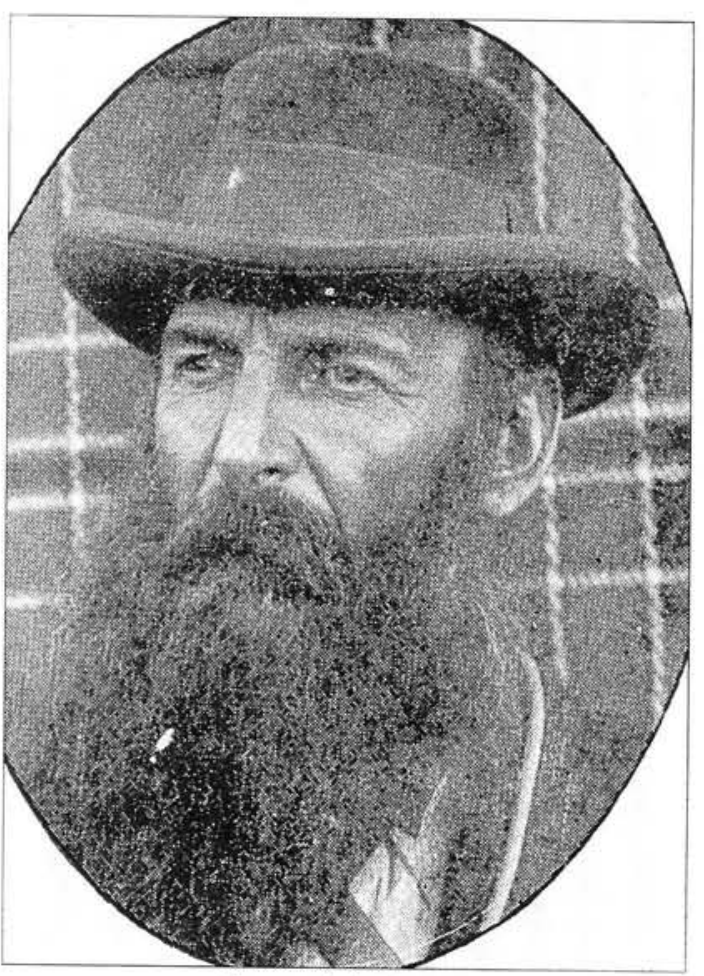

General de la Rey horses ribs as the gaunt animals staggered forward in a daze, came the stunning news that Prinsloo had surrenderd with 4000 men.

At the only place where hope of finding sanctuary existed, in the Magaliesberg. Clements ${ }^{12}$ was lying in wait for the Boers. The Transvaal and Free State commandos split up and rode off in different directions, Pienaar remaining with the former. At a temporary halt he obtained a pass from Liebenberg and set off through the dense bush to Middelburg. After encountering an ammunition wagon train destined for General de la Rey,,$^{13}$ Pienaar joined up with Steyn. The small band of fifty men protecting the president were attacked by a British force under Lord BadenPowell, who had set out from Pretoria expressly to intercept this group. At Pienaarsriver the commando kept the enemy at bay long enough to give the group a decent start. They mando saved their guns and themselves, presumably, because the enemy were unaware of their real numbers.

The commando joined up with Liebenberg's 600 men who had just retaken Klerksdorp. After a few small skirmishes in which the Boers played hide and seek with the British (Pienaar had a substantial part), they entered Potchefstroom, and raised the Vierkleur on the Government building. Then, after a day, the order was relayed through the billet houses to saddle up and meet at Frederikstad. After a long retreat with nearly 3000 haggard men, beating a mechanical tattoo on their found Middelburg in enemy hands and made for Roossenekal, where, once again, the British were ahead of them.

The commando then headed towards Machadodorp, from whence General confer with President Steyn. At the town a train was waiting. Pienaar described the scene in his diary: "The station is crowded with Transvalers, all eager to shake their gallant Free State brethren by the hand. The president and party enter the carriage, the engine whistle blows and the train speeds down to Waterval Onder, where Paul Kruger and his advisers are impatiently awaiting its arrival." Schalk Burger had left to meet and

\footnotetext{
Commandant D.P. Liebenberg (1869 - 1935).

Lord S.P. Methuen (1845 - 1932).

General R.A.P. Clements (1855 - 1909).

General J.H. Koos De la Rey (1847 - 1914).
} 


\section{THE END OF THE WAR}

The battle of Machadodorp, on the second day after Steyn's arrival at Waterval Onder, was characterised by a furious bombardment. The British were victorious and the Boers in full retreat. This signalled the end of conventional warfare and Steyn proposed the immediate introduction of guerrilla tac-

tics: Generals. Pienaar and Kemp supported him in this. ${ }^{14}$ Kruger, however, was determined to defend the railway to the last. His Government retreated by train to Nelspruit and thence to Hectorspruit with the Commandos following by rail and road. The Boer forces were then divided and it was decided that President Kruger should leave for Holland. with General Schalk Burger acting in his place.

After Kruger's departure, Steyn was left temporarily in charge of the Transvaal Government. His last interview with Botha took place in the open air, in full sight of the burghers. Pienaar wrote "Louis Botha is idolised by his men perhaps he has not an enemy in the world - but it is to Steyn, and Steyn alone, that the honour belongs of the resistance still being offered by the Boers." 15

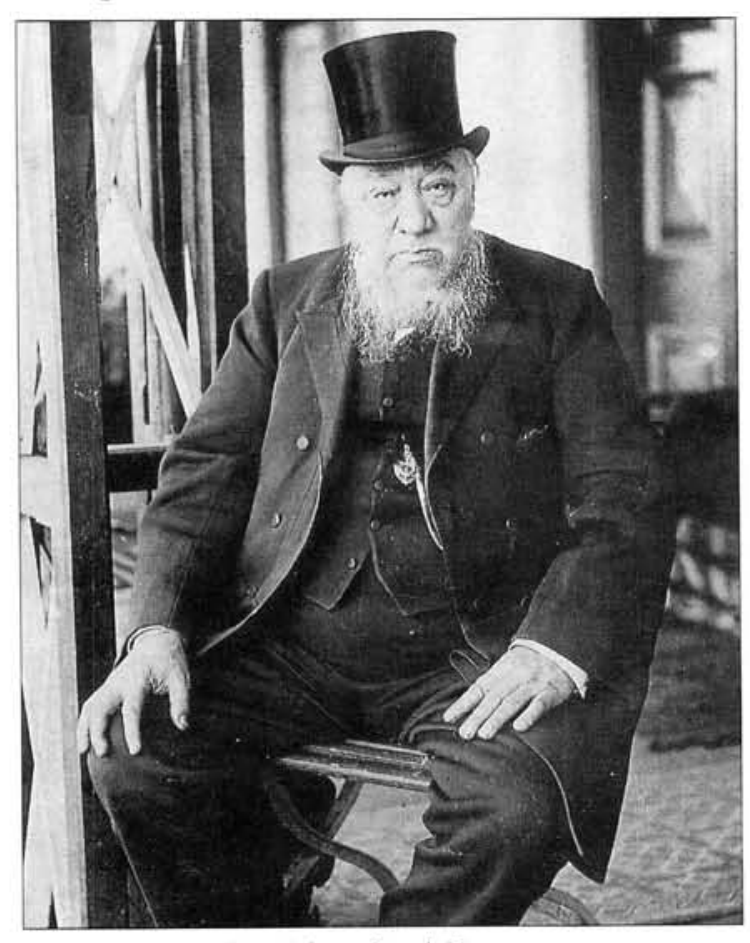

Presidem Pual Krager

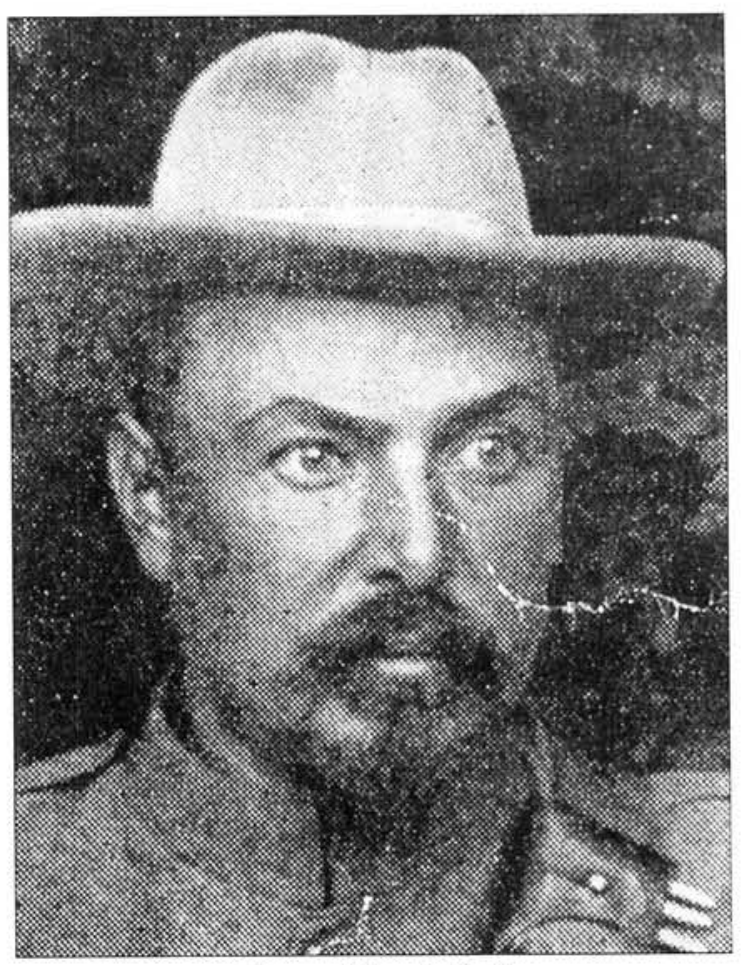

General Louis Botha
According to Pienaar, the scene around the station resembled a cattle market, "Near the line stands a policeman, his gaze fixed upon a large box filled with gold at his feet. General Ben Viljoen, standing on a wagon, addresses the men, explaining to them what guerilla warfare means. Hats, shirts, etc, are being dealt out with a lavish hand. Some burghers wander off into the bush in search of game. others lie lazily stretched out beneath the tree. Trains crammed with men arrive from the rear; discharge their loads, and are immediately boarded by the dismounted men destined for Komatipoort. The line is blocked with traffic."

When Pienaar arrived at Hectorspruit he was told that the Chief of the Telegraphic Department of the Zuid-Afrikaansche Republiek, C.K. van Trotsenburg, had left for the Netherlands. Pienaar was subsequently promoted to Chief in the Field. He received an order from President Steyn to fetch equipment at Lourenço Marques and set off on the mission into Portuguese territory. He was accompanied by Pieter Jacobus Schutte, a member of the First Volksraad for Lydenburg and Chief of the Commissariat, and De

14 General J.C.G. Kemp (1972 - 1946) and General Francois Joubert Pienaar (1856 - 1932) Uncle of F.F. Pienaar.

15 F.F. Pienaar, pg 170. 
Boer, Secretary to General J.P. Coetzer. They left Komatipoort on 13 September 1900 for Lourenço Marques and returned five days later. Upon their arrival at Moveni station on the Portuguese side, the stationmaster stopped them and showed them a telegram from Lourenço Marques which forbade them to travel further by rail. A detachment of soldiers under the command of a Lieutenant Garcia was present. Pienaar could understand a few words of Portuguese and via the Lieutenant he tried to receive some clarification on their situation from the stationmaster. The latter stated quite categorically that he had to observe his orders and that the group were not permitted to make further use of the railway. On foot they were free to go wherever they pleased, however, the Portuguese warned Pienaar and his companions that the borders were well guarded and that any attempt to cross them was bound to fail.

Pienaar and the men went to a shop near the station in an attempt to hire horses or bearers to carry their luggage. Nothing was available, however, so Schutte sent urgent telegrams to Consul Gerard Pott in Lourenço Marques and to General Coetser but no replies were received. During the late afternoon a train arrived from the direction of Komatipoort. Pienaar went to the stationmaster requesting tickets against payment. As the request was refused they then hid aboard the train without tickets.

When Pienaar's group arrived in Lourenço Marques the next day they consulted Consul Pott who indicated that he had been informed by the Governor, that, with a view to Portugal's neutrality nobody was permitted to return to the Republic. Pienaar's efforts to return to the Transvaal had consequently failed.

The war was "practically over", Lord Roberts told an audience in Durban at the beginning of December. President Kruger, who, after weeks as a fugitive in a railway carriage, had finally crossed over the border of Moçam- bique on 11 September and embarked on a ship bound for Europe. (The Gelderland, a Dutch cruiser, had been sent by Queen Wilhelmina to fetch him.)

Routed at the Battle of Belfast (Dalmanutha), Louis Botha's army split into fragments. These were pursued by three British armies - Buller's to the north, General French's at the centre and Generals Pole-Carew and Ian Hamilton towards the east. ${ }^{16}$ The British armies were thus sweeping three thousand Boers before them down the railway line towards Komatipoort and the Moçambique frontier. They did not, however, inflict many casualties.

In an effort to force the Boer Commandos into surrender, Lord Roberts, GOC of the British forces in South Africa, sent Boer women and children to the Boer lines. Not only did this hamper the commandos' mobility but they no longer had acsess to the necessary food. Barberton became the collection point for these women and children until the town was occupied by General J.D. French's troops on 13 Sept 1900. There was a singular lack of accommodation and water and Lord Roberts insisted that General Botha remove them from Barberton. These people eventually found their way to Lourenço Marques.

Influenced by the arguments of the Portuguese, one of which was that, should the British cross the Portuguese frontier and attack the Boers from behind, Portugal would not be able to prevent it, and by the fact that the position first chosen for the entrenchments lay within a mile of the frontier and therefore could not be occupied. a Krygsraad resolved to follow the President's advice and to retire to Moçambique.

General F.J. Pienaar was about to blow up the international railway bridge across the Inkomati river. The bridge had already been mined, the gun placed in position, and everything made ready to give General PoleCarew and his troops a worthy recep- 
tion when fate decided differently. The cause of this incident was the instructions that were issued by President Kruger not to proceed with the ambush. Kruger did not wish to embarrass the Portuguese, as they had a centuries' old non-aggression treaty with the British. And persuaded by a senior Portuguese officer, General Pienaar ordered his forces not to blow up the bridge.

Towards the middle of September 1900 there were about 3000 burghers in Komatipoort. Most of them were without horses and consequently unable to flee before the advancing British forces. When the British troops approached the border post, on the night of 22 September 1900, General Pienaar crossed the border into Moçambique with some 700 Boers. According to an account by a Portuguese officer, he saw in the dark what looked like fireflies on the railway line as about 70 railway trucks, loaded with ammunition, were pushed over the border into Moçambique. One of the big fellows sitting on top of the ammunition trucks was a burly Irish volunteer smoking his pipe on top of all that ammunition. When reprimanded he got down from the truck sulkily, tapping out his pipe against the truck door.

By 27 September 1900 the force had completed its move to Moçambique. General Pienaar then ordered his forces to lay down their arms (an example later followed by other burghers). Towards the end of the month a larger group, which included women and children, crossed the border. Numbering about one thousand they used the international bridge and once again there were no incidents. The British gave up chase as soon as they realised that the Boers were heading for the bridge. Those who were armed laid down their weapons without protest and a special train carried them off to Lourenço Marques.

Amongst the Boers who crossed the Moçambique border were leading figures such as Gen F.J. Pienaar and

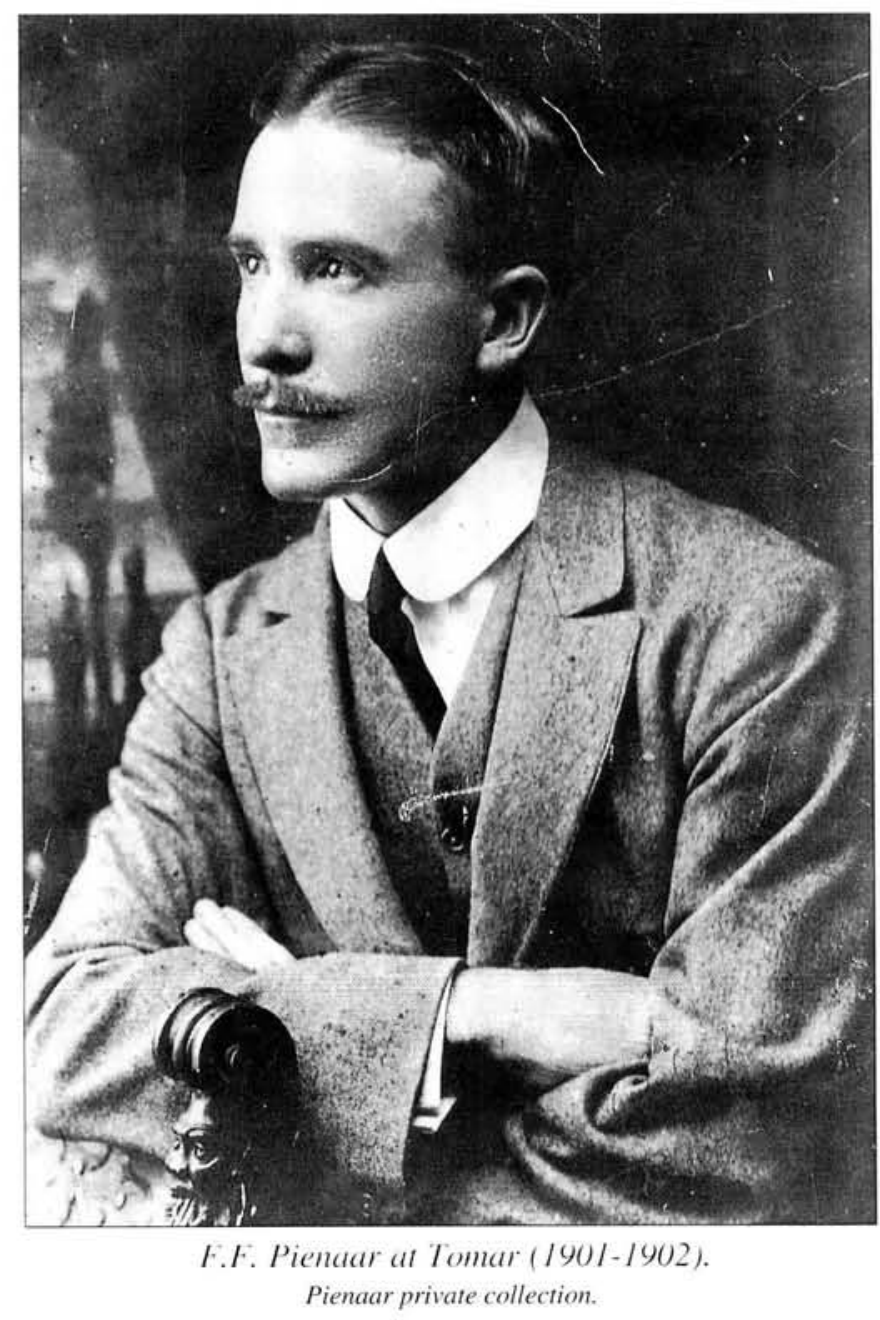


Commandants H.P. Mostert, N.J. Grobler and W.J. Geerling. ${ }^{17}$ All in all, at the time of their crossing, about two thousand Boers and foreign volunteers surrendered to the Portuguese colonial authorities. This was after having made a spectacular bonfire from fifteen hundred railway trucks and their contents and abandoning their last Long Tom and British 12 pounders captured at Sannah's Post. ${ }^{18}$

In Lourenço Marques the Boer families were accommodated in rented homes and rooms. Nearly 800 burghers were initially interned in the local police station, while the rest lived in tents. Flippie Pienaar wrote a letter to his sister on 16 September 1900:

\section{"Dear Sister,}

After our retreat to Glencoe I was transferred to the Free State where we had any amount of work to do. When Pretoria was taken I tried to go back but we were cut off at Greylingstad and had to turn back to Bethlehem.

I left Fouriesburg with De Wet and after crossing the railway Frank and I went on ahead to near Potchefstroom. We stayed there till De Wet came up, and accompanied him to Rustenburg, where I left Frank with the Rustenburg Commando. I then came through to Machadodorp with President Steyn and joined our staff there. Johan and Giep were together with Dericksens (Boksburg) Commando, but I had no opportunity of seeing them, and don't know whether they have surrendered and gone home, or whether they are still at it.

There is no more work for us, so we are all going on Commando. I return to Hectorspruit tomorrow.

Oom Frans is General. His wife and children are with him. Tell Louisa Johan is Fieldcornet and a very good one. Van Aswegen and all our relatives and friends are well.
In case you reply, address to Oom Frans at Komatipoort, who may be able to forward.

We do not expect to see you for a long time, but events follow so unexpectedly that one can make no definite plans. My idea is to stick to Louis Botha to the last, so where he is, you will know I shall also be.

\section{With Love all, Philip."}

\section{FROM LOURENÇO MARQUES TO PORTUGAL}

The government of the ZuidAfrikaansche Republiek, after receiving a letter from Lord Roberts dated 2 September 1900, in which he threatend to remove more women and children from the occupied areas, started to make provisional plans for those who would perhaps be sent to the Boer lines. President Kruger and General Louis Botha then established a Commission for ZAR Refugees (Commissie voor de Refugees uit de ZAR). This Commision was to be entrusted with the care of future deportees and those officials who could not join the fighting burghers after the commandos turned away from the railway line.19 Initially the Commission comprised N.S. Malherbe (Treasurer General ZAR), J.S. Marais (Auditor General ZAR), I.N. van Alphen (Postmaster General ZAR) and W.J. Geerling (Assistant Chief Telegraph Service ZAR). ${ }^{20}$

The Commission started its work on 18 September 1900 in Lourenço Marques. As a result of the disarmed burghers crossing the border at Komatipoort, it was compelled to cater for that group as well, which eventually numbered about 1400 people. After they had handed over their rifles, ammunition and horses to the Portuguese, the group entrained for Lourenço Marques under escort and was interned in the local police barracks. After members of the former Uitlander units had been sent away, a number of the refugees were housed in tents while families

\footnotetext{
17 Wouter J. Geerling was Assistant Chief of the Zuid-Afrikaansche Republiek Telegraphic Department under D.K. van Trotsenburg.

Ferreira, 1988

Ploeger: 1990:21:16

Leyds Archives 93 (A) as quoted by Ploeger, 1990:21:17).
} 
found accommodation in rented houses. Initially the Portuguese authorities provided food for all. Later the Commission supplemented the nearly exhausted supplies with stocks that had been purchased earlier by the Republican Government and not sent to the Transvaal but stored locally.

When Malherbe and Van Alphen left for Europe their vacancies on the Commission were filled by P.J. de Kock and A. de Villiers. The Commission enabled 22 colonial Afrikaners and 42 ex-officials to depart for Europe and America, including general Ben Viljoen and two children. Mrs Marais and the wives of some senior officials. The travelling expenses to Europe and America of Cape and Natal Afrikaners were paid for, as they would have experienced difficulties in returning to their homes in the two British colonies.

Co-operation between the Commission and the Portuguese authorities was good and, as the Governor of Moçambique feared that the ex-members of the Uitlander corps could perhaps cause difficulties, the Commission co-operated fully in removing them from Lourenço Marques. All Irish and American volunteers were put aboard a Portuguese man-of-war. The Commission also chartered the Austrian ship Styria to take 300 foreigners to Trieste. while others were sent to Madagascar.

In Lourenço Marques the sick were treated in a Dutch Ambulance train which was permitted to remain at the station for a while. When the Governor of Lourenço Marques ordered personnel and patients to evacuate the NZASM railway trucks, Consul General Pott offered the use of his house. This building could accommodate $70 \mathrm{pa}$ tients instead of the 40 of the ambulance train. However, on 15 November 1900 the Portuguese Governor of the Province Moçambique informed Pott in writing that his recognition to act as consul general of the ZAR and the OVS had been withdrawn. The reason given was that Pott was suspected of receiving smuggled correspondence, although no evidence was ever presented. Leyds' belief that pressure on the Portuguese authorities by the British government led to this action was not altogether unfounded. ${ }^{21}$

Pott was, in actual fact, a very important link between the Commission and the local Portuguese authorities and it was decided, in collaboration with Pott, that the Commission would in future keep a lower profile. The Governor General regarded General Pienaar. who had crossed the border with the larger number of the burghers, as the representative of the refugees. The Commission was thus compelled to accept him as the middle man.

Pienaar, however, was not regarded as a true representative of the Boer interests by the Afrikaners themselves. The reason for this being that he had made a promise to the Governor General that if he and his family could live in Lisbon, he would use his influence to persuade the refugees in Lourenço Marques to hand themselves over to the British authorities. Naturally the British consul was in favour of making use of General Pienaar's influence. Even before the British War Office had agreed to such action, General Pienaar had addressed the burghers in the Lourenço Marques barracks on 19 November 1900 about handing themselves over to the British authorities. He also mentioned the possibility of departing overseas as the Portuguese authorities had restricted the freedom of movement of burghers accommodated in the overfull barracks. As a result of this persuasion 44 burghers subsequently agreed to surrender. Shortly afterwards General Pienaar stated that he had been informed that the British authorities would be satisfied if 115 burghers would turn themselves over to the British authorities.

While the activities of the Commission were closely watched by the Portuguese, it became abundantly clear that, despite the relocation of the burghers to more salubrious barracks near the sea, for those Boers who were not prepared to submit to the British authorities the only solution was to seek better living conditions overseas. Due to General Pienaar's efforts 115 burgh-

21 Ploeger : $1990: 21: 20$. 


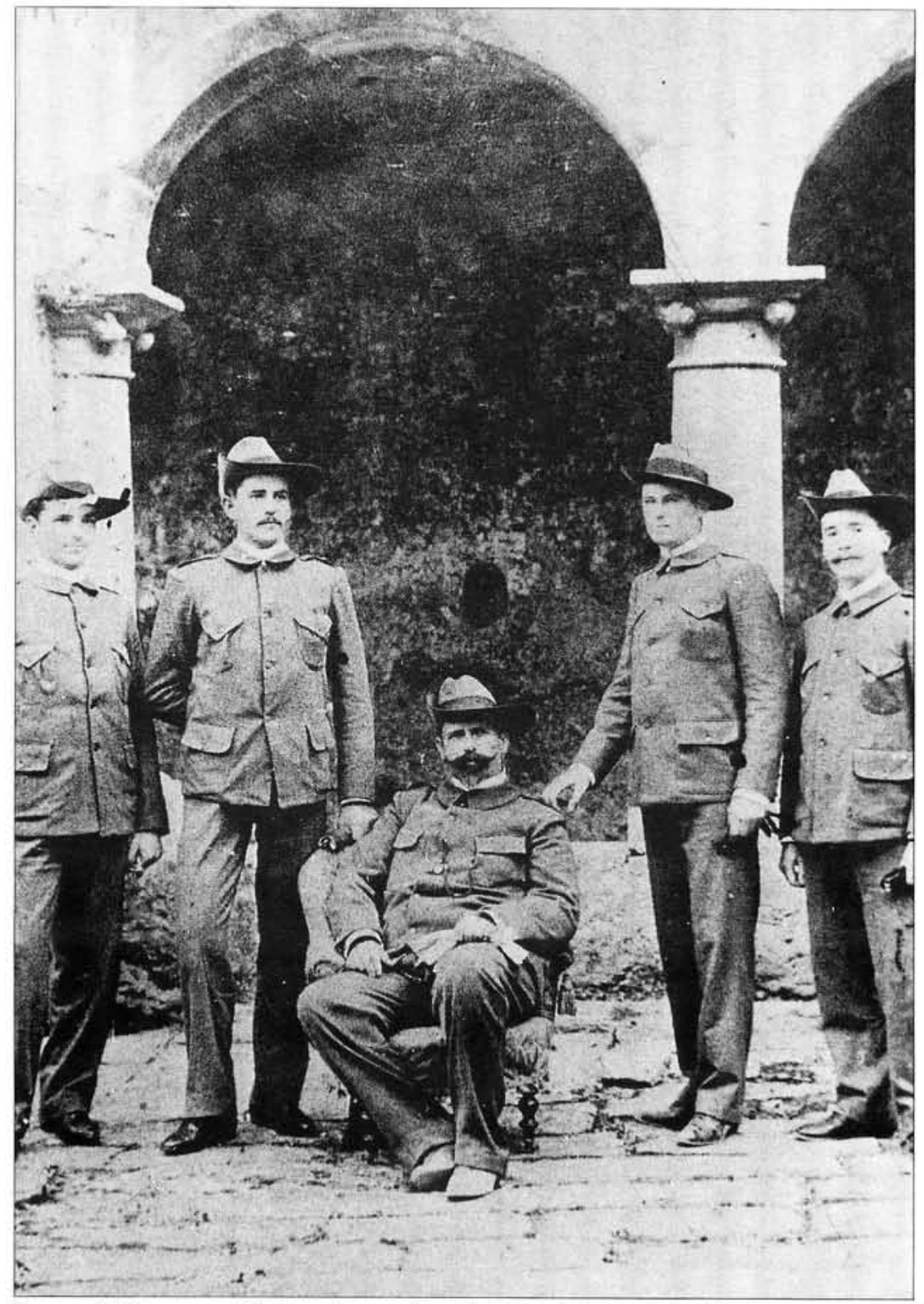

General Pienaar at Tomar (seated) with from left to right his three sons at the extreme right, his secretary and nephew F.F. Pienaar. All are in Boer uniform.

Pienaar private collection.

ers were prepared to surrender to the British. These refugees requested to be sent to the Cape, which was possible since Sir Alfred Milner had given approval for 300 refugees to settle in the Colony. In this way the Portuguese would be released from the administrative and financial burden of looking after the refugees. Yet when the Portuguese ambassador in London put this request to the British Foreign Office, the reply was that it was not convenient for the British. The reason given being that: "to receive the Boer refugees who, not being prisoners of war, might after submitting themselves, join the rebels, and that if Her Majesty's Government objected to receive them the Portuguese authorities must keep them". 22 The British Government was, however, in principle, prepared to pay a reasonable compensation to the Portuguese Government in connection with the maintenance of the refugees. ${ }^{23}$

All of these factors left the Commission feeling powerless and friction between the Commission and General Pienaar increased. Relations worsened because the Commission did not accept the fact that General Pienaar had

22 Leyds-Archives 93 (B), GZR 1953/01. Memorandum Kommissie-drW.J. Leyds, 30 December 1900 (in: Ploeger 1990:21:23).

23. Dr Leyds noted in his memorandum that General Botha had informed him in September 1902 that General Pienaar had. amongst other things, been in the Barberton goal for fraud. He was released prior to the arrival of the British occupation forces on condition that he join a commando, and had later managed to become a general. 
been duly appointed as a general as, according to Geerling, he had not received his appointment from General Botha. ${ }^{24}$ Pienaar threatened Geerling with arrest and following this all co-operation between Pienaar and the Commission ceased.

Conditions for the refugees in Lourenço Marques worsened and Malaria, colitis and other diseases broke out. All types of rumours began to circulate: for instance that the Portuguese Government had decided to send the refugees to the Cape Verde islands, or the rumour that the war had apparently ended on 15 January 1901, according to remarks made by Pienaar.

Unbeknown to the Commission and General Pienaar, however, the Governor General in Lourenco Marques had received the instruction from his government to offer Boer refugees a chance to go to Europe by ship. Those who refused, could find a temporary home in other Portuguese colonies.

The British Government's reaction to this offer was that as Portugal was giving asylum to refugees of the armed forces of a country at war with Britain. it would be compelled, in terms of international law and because of its bonds of friendship with Britain, to intern these refugees until the end of the war. As far as the British Government was concerned these refugees could be interned in any Portuguese area, in Europe or elsewhere, but were not allowed to leave the area of internment. The British government reiterated its promise to recompense the Portuguese authorities for its supervision and maintenance of the refugees. The Portuguese Government then instructed the Governor General in Lourenco Marques that no prisoners could leave Lourenco Marques unless they were interned elsewhere on Portuguese territory.

On 4 January 1901 General Pienaar had an interview with the Governor General and was requested to indicate on a list which burghers could afford to go to Europe at their own expense. General Pienaar replied that nobody was financially capable of doing this. The Governor General then questioned Pienaar as to where the funds came from for those people who not supported by the Portuguese Government. Pienaar replied that this was done by

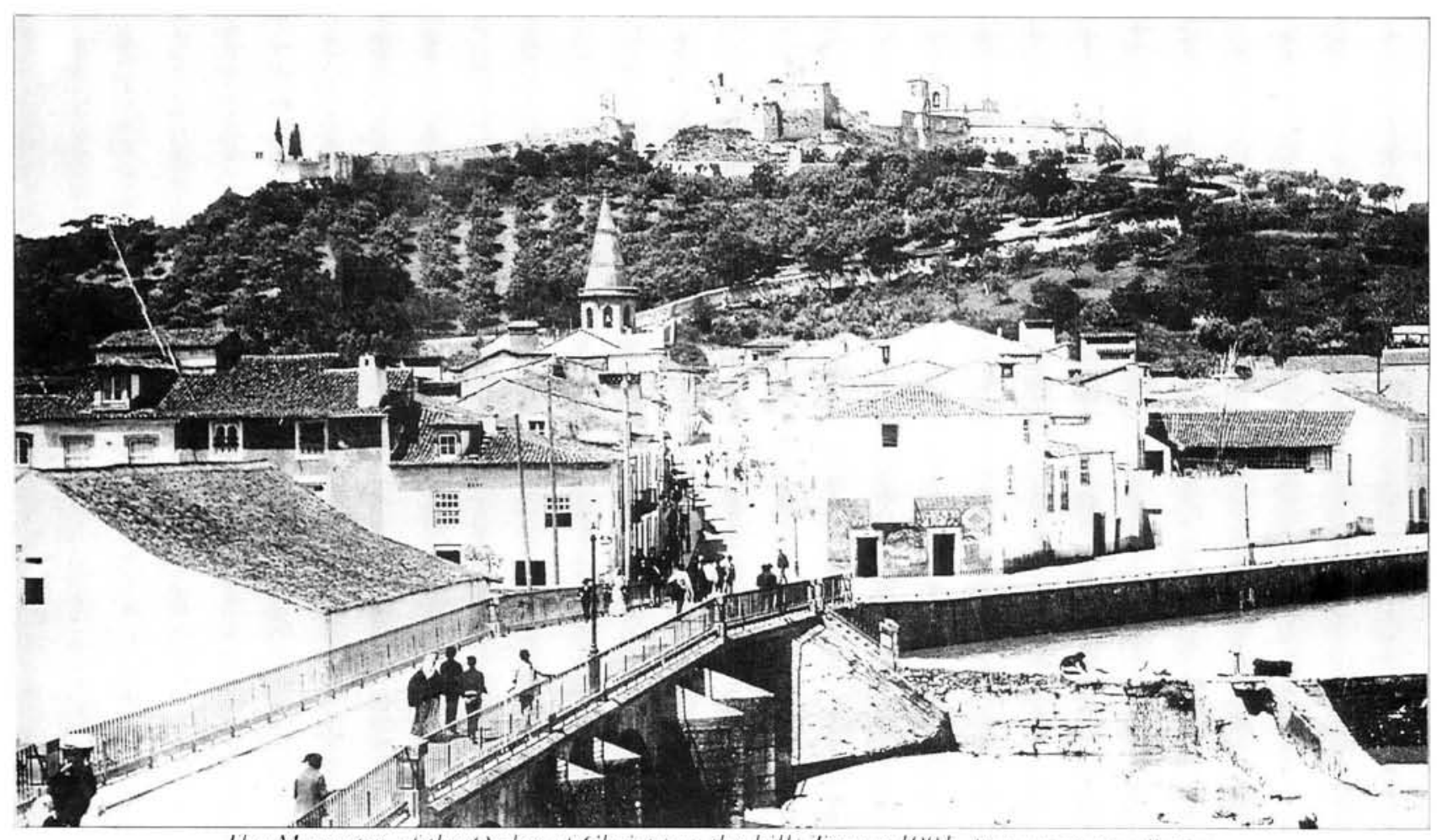

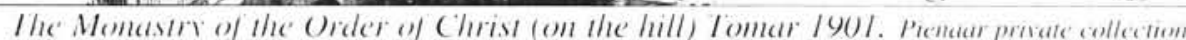

24 Proven to be incorrect as F.J. Pienaar had been made Combat General in the field on 15 September 1900 and in his letter to General Pienaar Van Boeschoten, Secretary of Kruger, addressed F.J. Pienaar as Combat General (Vechtgeneraal). 
way of charities. When the Governor General implied that the Commission was being provided with funds by the Transvaal Government, Pienaar replied that he was unaware of such funds. The Governor General then reiterated that it was in Portuguese interests to remove the refugees from Lourenço Marques. He also affirmed that their passages to Europe would be at the expense of the Portuguese Government. General Pienaar was asked to go to Europe in order to make the necessary arrangements with the Portuguese Government.

On 10 November 1901, the Commission for Refugees decided to make available, free of charge, as much food as was necessary for the refugees. The Commission was aware of the increasing number of these people and it was decided to make $£ 200$ available to General Pienaar, so as to enable him and his family to depart for Lisbon. General Pienaar was to leave aboard the warship Alfonso d'Albuquerque for Lisbon where he would be interned. The remaining refugees would leave Lourenço Marques on the two ships Zaire and Benguella.

Before the Benguella departed to Portugal on 26 February 1901 with about 700 burghers on board, Governor M. de L. Machado made it known that the refugees would remain in Portugal for the duration of the war unless they expressed the wish to be sent to another part of the Portuguese empire. The Portuguese government undertook to provide free accommodation and food for anyone who required it. When the war ended all refugees would be transported free of charge to Lourenço Marques or another port in Southern Africa.

In addition to the \pm 700 burghers there were also a large number of stranded ex-officials from the ZAR on board, as well as the Dutch ambulance staff and about 150 patients. General Pienaar fell foul of the Governer when he illegally removed two Transvaal ex-officials (Van der Walt and Janssens) from the ship Gironde. After this incident the Governor indicated that he did not regard General Pienaar as the leader of the burghers. Accordingly Cmdt H.P. Mostert acted as the chief of the burghers on board the Benguella.

The rest of the refugees left Lourenço Marques aboard the Zaire on 8 March 1901. Both ships had arrived in Portugal by April 2, 1901. They had sailed down the coast, rounded the Cape and steamed up along the west coast of Africa to Portugal.

A daughter of Field Cornet Oosthuizen who hailed from Johannesburg ${ }^{25}$ remembered the day she departed with other women and children from the city for the Boer lines. On the train national anthems were sung. There were 17 Republic flags on board and on the flag Miss Oosthuizen bore the words Wij gingen onze Broeders tegemoed were embroidered. ${ }^{26}$ At Germiston station the town's English-speaking population commiserated with the women and children, amongst whom were babies of only a few days old. En route to Pretoria religious songs were sung, at the city itself the women and the children had to remain in the trucks while food was issued under the guard of British soldiers. The bitterly cold night was spent in the open trucks. Early the following morning the train departed. At each station national anthems were sung and after a two day journey the company arrived in Belfast, where the the open trucks were exchanged for closed compartments.

On arrival at Kaapmuiden Miss Oosthuizen received permission to join her father who, together with other burghers, was guarding the bridge at Komatipoort. As the railway line was cut, she had to remain there and after the British troops had occupied the border post, she entrained for Lourenço Marques where armed Portuguese soldiers drove the women and children to a building on the station premises. The next day they went on to a tent camp. Later Miss Oosthuizen was accommodated in a pleasant house at Reuben Point and after many privations boarded the Zaire on 
8 March 1901. On arrival in Lisbon on 6 April 1901 the women and children were sent on to Caldas da Rainha. ${ }^{27}$

On 22 February 1901, shortly before the departure of the Zaire from Lourenço Marques to Portugal, Cmdt H.P. Mostert appointed an ex-official from the ZAR, Meindert Noome, as Veld-kornet with the task of supervising the burghers and their families who would undertake the sea journey around the Cape of Good Hope to Lisbon. With a view to the differences in the climate to be expected in Portugal, the Refugee Commission in Lourenço Marques provided the passengers of the Benguella and the Zaire with adequate shoes, clothes and coats.

Anna Cornelia Kruger escaped with the last train from Barberton. When it arrived in Lourenço Marques passengers complained of the unbearable heat, fleas and fever. According to her the Zaire was dirty and infested with fleas, the food, prepared according to Portuguese custom with a lot of oil, was inedible to the Boers. At Caldas da Rainha, where she was interned, the station was packed with inquisitive Portuguese "die komt kijk naar de boeren want hulle hebben altijd gehoort dat de boeren lang ooren en lang haren heeft en hulle was verwonderd om te zien wat voor een goede en mooie natie het is en toe moest ons daarvandaan met die voet stapt zoo ver als ons deur die straaten loopt staande Portugeuschen weerskanten in de straat aanmekaar en gooit ons met roos bladeren en schreeuwen leef de boeren leef de boere". ${ }^{28}$

*Brig (Dr) J.H. Picard SM, is Director Language Service, $S A D F$.

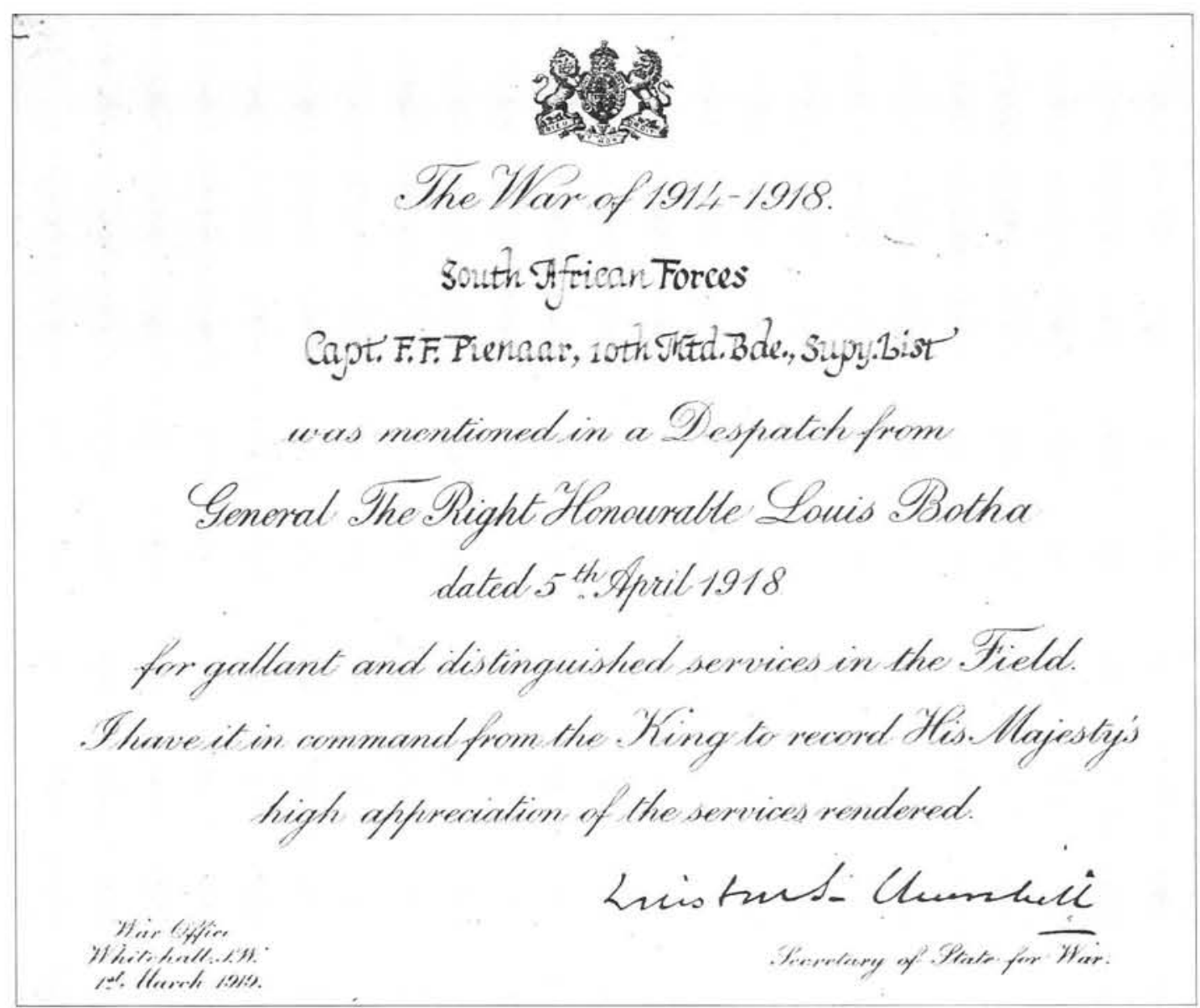

Capt F.F. Pienatar of IOth Mounted Brigade mentioned in despatches by General Louis Botha in the 19141918 War (German South West Africa). The certificate signed by Winston Churchill, Secretary of State of War. Pienaar private collection.

27 Ploeger (1990:21:36).

$28 \mathrm{TAB}$, Acquisition W/19/1 (PHS van Zyl collection) "Herinneringen van Anna Cornelia Kruger". Translated into English, this means: "Who came to view the Boers for they had always heard that the Boers have long ears and hair and they were amazed to see what good and beautiful people they were and then we had to walk through the streets on foot the Portuguese lining the street and pelting us with rose petals, shouting 'long live the Boers'." 


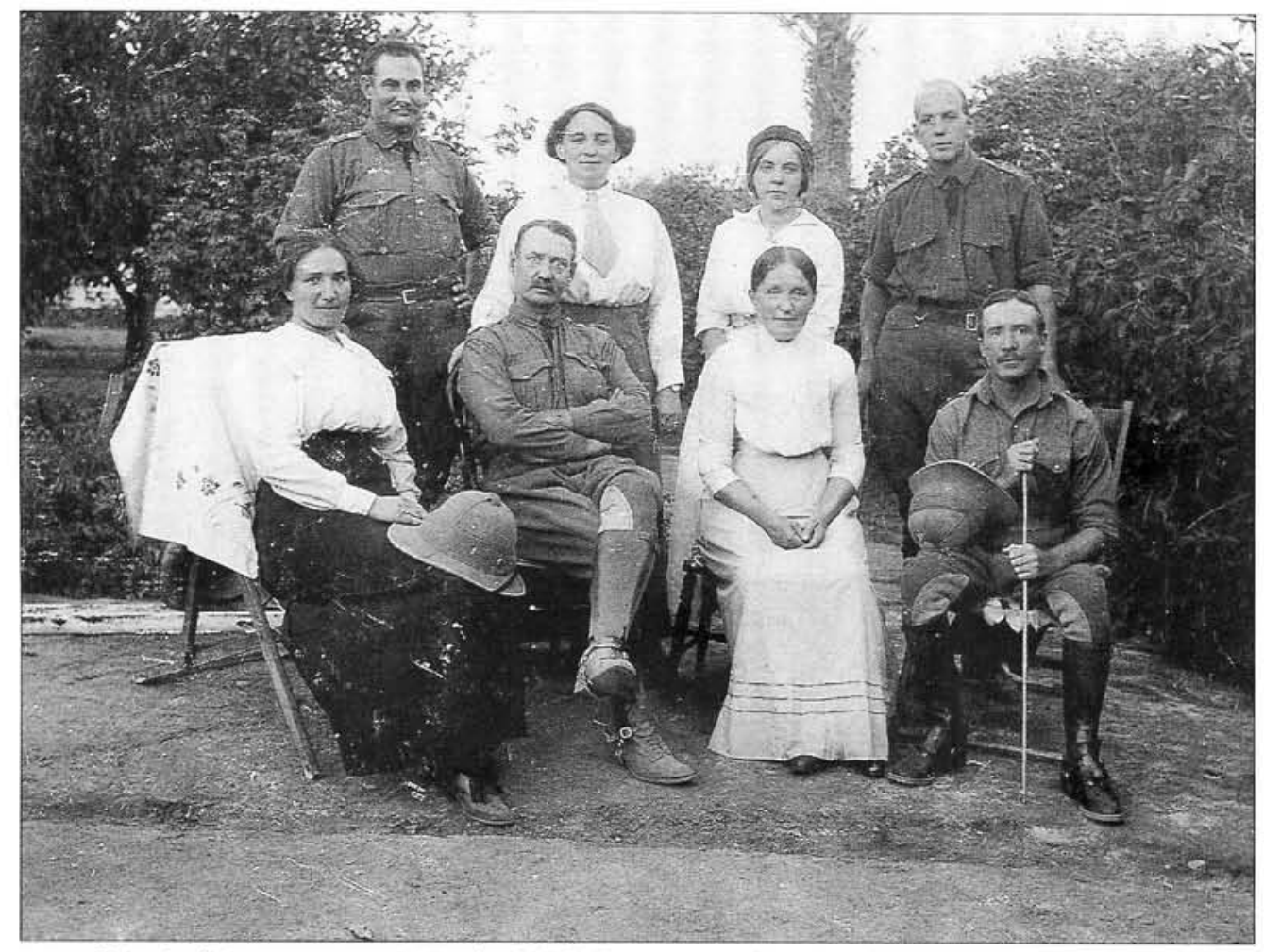

Flippie Pienatr, captain in the UDF Forces, on the eve of the German South West

Campaign in 1915, together with fellow officers and their wives. Pienaar is seated on the extreme right. (Pienaar private collection.)

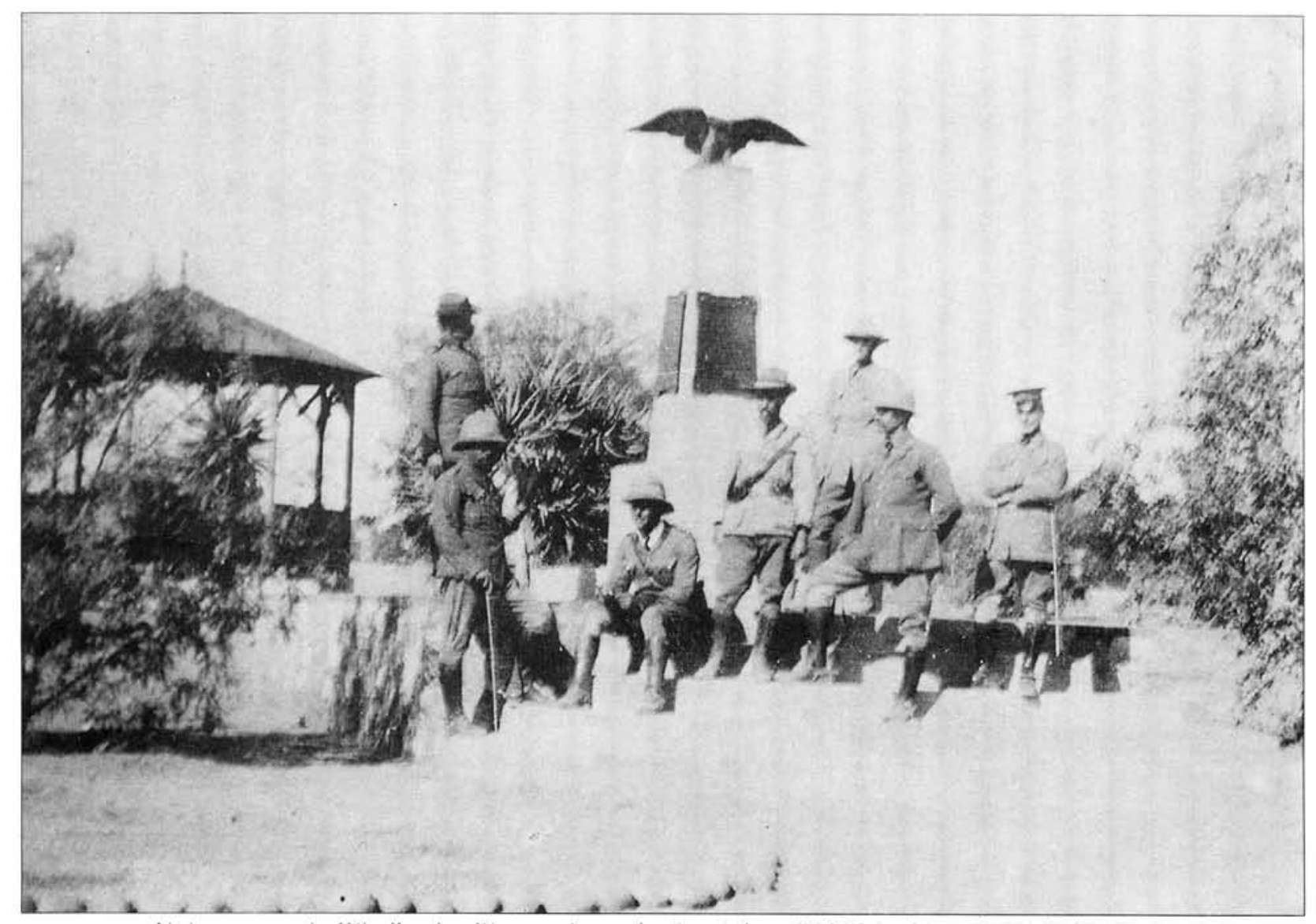

Union troops in Windhoek; Pienaur is on the far right. (SADF Archives DOC 78/003969). 